University of Nebraska - Lincoln

DigitalCommons@University of Nebraska - Lincoln

\title{
Evaporative loss from irrigated interrows in a highly advective semi-arid agricultural area
}

\author{
Nurit Agam \\ Gilat Research Center, agam@agri.gov.il \\ Steven R. Evett \\ USDA-ARS \\ Judy A. Tolk \\ USDA-ARS \\ William P. Kustas \\ USDA-ARS
}

Paul D. Colaizzi

USDA-ARS

See next page for additional authors

Follow this and additional works at: https://digitalcommons.unl.edu/usdaarsfacpub

Agam, Nurit; Evett, Steven R.; Tolk, Judy A.; Kustas, William P.; Colaizzi, Paul D.; Alfieri, Joseph G.; McKee, Lynn G.; Copeland, Karen S.; Howell, Terry A.; and Chávez, Jose L., "Evaporative loss from irrigated interrows in a highly advective semi-arid agricultural area" (2012). Publications from USDA-ARS / UNL Faculty. 1139.

https://digitalcommons.unl.edu/usdaarsfacpub/1139

This Article is brought to you for free and open access by the U.S. Department of Agriculture: Agricultural Research Service, Lincoln, Nebraska at DigitalCommons@University of Nebraska - Lincoln. It has been accepted for inclusion in Publications from USDA-ARS / UNL Faculty by an authorized administrator of DigitalCommons@University of Nebraska - Lincoln. 


\section{Authors}

Nurit Agam, Steven R. Evett, Judy A. Tolk, William P. Kustas, Paul D. Colaizzi, Joseph G. Alfieri, Lynn G.

McKee, Karen S. Copeland, Terry A. Howell, and Jose L. Chávez 


\title{
Evaporative loss from irrigated interrows in a highly advective semi-arid agricultural area is
}

\author{
Nurit Agam $^{\mathrm{a}, *}$, Steven R. Evett ${ }^{\mathrm{b}}$, Judy A. Tolk ${ }^{\mathrm{b}}$, William P. Kustas ${ }^{\mathrm{c}}$, Paul D. Colaizzi ${ }^{\mathrm{b}}$, Joseph G. Alfieri ${ }^{\mathrm{c}}$, \\ Lynn G. McKee ${ }^{c}$, Karen S. Copeland ${ }^{\text {b }}$, Terry A. Howell ${ }^{\text {b }}$, Jose L. Chávez ${ }^{\text {d }}$ \\ ${ }^{a}$ Gilat Research Center, Agricultural Research Organization of Israel, Rural delivery Negev 85280, Israel \\ ${ }^{\mathrm{b}}$ USDA-ARS Conservation \& Production Research Laboratory, P.O. Drawer 10, Bushland, TX 79012, USA \\ ${ }^{\mathrm{C}}$ USDA-ARS, Hydrology E Remote Sensing Lab, Bldg. 007, BARC-West, Beltsville, MD 20705, USA \\ ${ }^{\mathrm{d}}$ Department of Civil and Environmental Engineering (CEE), Colorado State University, Fort Collins, CO 80523, USA
}

\section{A R T I C L E I N F O}

\section{Article history:}

Available online 20 July 2012

\section{Keywords:}

Soil evaporation

Transpiration

Irrigated row-crop

Row orientation

\begin{abstract}
A B S T R A C T
Agricultural productivity has increased in the Texas High Plains at the cost of declining water tables, putting at risk the sustainability of the Ogallala Aquifer as a principal source of water for irrigated agriculture. This has led area producers to seek alternative practices that can increase water use efficiency (WUE) through more careful management of water. One potential way of improving WUE is by reducing soil evaporation $(E)$, thus reducing overall evapotranspiration (ET). Before searching for ways to reduce $E$, it is first important to quantify $E$ and understand the factors that determine its magnitude. The objectives of this study were (1) to quantify $E$ throughout part of the growing season for irrigated cotton in a strongly advective semi-arid region; (2) to study the effects of LAI, days after irrigation, and measurement location within the row on the $E / E T$ fraction; and (3) to study the ability of microlysimeter (ML) measures of $E$ combined with sap flow gage measures of transpiration $(T)$ to accurately estimate ET when compared with weighing lysimeter ET data and to assess the $E / T$ ratio. The research was conducted in an irrigated cotton field at the Conservation \& Production Research Laboratory of the USDA-ARS, Bushland, TX. ET was measured by a large weighing lysimeter, and $E$ was measured by 10 microlysimeters that were deployed in two sets of 5 across the interrow. In addition, 10 heat balance sap flow gages were used to determine $T$. A moderately good agreement was found between the sum $E+T$ and $\mathrm{ET}$ ( $\mathrm{SE}=1 \mathrm{~mm}$ or $\sim 10 \%$ of ET). It was found that $E$ may account for $>50 \%$ of ET during early stages of the growing season $(\mathrm{LAI}<0.2)$, significantly decreasing with increase in LAI to values near $20 \%$ at peak LAI of three. Measurement location within the north-south interrows had a distinct effect on the diurnal pattern of $E$, with a shift in time of peak $E$ from west to east, a pattern that was governed by the solar radiation reaching the soil surface. However, total daily $E$ was unaffected by position in the interrow. Under wet soil conditions, wind speed and direction affected soil evaporation. Row orientation interacted with wind direction in this study such that aerodynamic resistance to $E$ usually increased when wind direction was perpendicular to row direction; but this interaction needs further study because it appeared to be lessened under higher wind speeds.
\end{abstract}

(c) 2012 Elsevier Ltd. All rights reserved.

\footnotetext{
The U.S. Department of Agriculture (USDA) prohibits discrimination in all its programs and activities on the basis of race, color, national origin, age, disability, and where applicable, sex, marital status, familial status, parental status, religion, sexual orientation, genetic information, political beliefs, reprisal, or because all or part of an individual's income is derived from any public assistance program. (Not all prohibited bases apply to all programs.) Persons with disabilities who require alternative means for communication of program information (Braille, large print, audiotape, etc.) should contact USDA's TARGET Center at (202) 720-2600 (voice and TDD). To file a complaint of discrimination, write to USDA, Director, Office of Civil Rights, 1400 Independence Avenue, S.W., Washington, D.C. 20250-9410, or call (800) 795-3272 (voice) or (202) 720-6382 (TDD). USDA is an equal opportunity provider and employer.

* Corresponding author. Tel.: +972 52 2292131; fax: +972 89926485.

E-mail addresses: agam@agri.gov.il, nurit.agam@gmail.com (N. Agam).
}

\section{Introduction}

Use of groundwater from the Ogallala aquifer as a source of irrigation water has transformed the High Plains into one of the largest and most productive agricultural regions in the United States [1], earning it the nickname "breadbasket of the world" [2]. Unfortunately, the agricultural productivity of the region has come at the cost of declining water tables, putting at risk the sustainability of the aquifer as a principle source of water for irrigated agriculture and other public requirements [3]. Groundwater depletion has increased pumping costs and reduced well flow rates. The decrease in profits of agricultural crop production in the region has led producers to seek alternative practices that can increase water use 
efficiency (WUE = economic yield per unit of water used) and thus increase the profitability of production systems. Some of these alternatives include increasing the portion of dryland (non-irrigated) farming, converting back to rangelands, applying conservation tillage, utilizing precision irrigation systems, and selecting different crops [4].

In terms of precision irrigation systems, increasing WUE is aimed at increasing the crop's use of applied water for growth and production, with minimum non-productive losses. This can be achieved by more careful consideration of the timing, frequencies, amounts and application methods of water. Water losses in agricultural systems can be attributed to runoff, deep drainage, or evaporation from the soil. Runoff occurs when irrigation or precipitation intensity is greater than the infiltration rate of the soil and ponded water exceeds surface storage capacity. Deep drainage occurs when irrigation amounts exceed ET for a long enough time to move water below the root zone. Both runoff and deep drainage are relatively easy to manage since irrigation intensity and amounts are controllable.

A third form of water loss is evaporation from the soil surface (E). Management (i.e., minimization) of $E$ has been reported by many to potentially be an effective measure to conserve soil water and improve crop WUE e.g. [5-7]. There is controversy regarding the definition of $E$ as a water loss. While many consider $E$ as a water loss that does not directly contribute to the production process [5-10], some claim that $E$ may indirectly benefit crop growth by maintaining a micro-climate within the canopy favorable to the growth and productivity of the plants e.g. [11-13]. Whether $E$ is a loss or a micro-climate moderator, it is agreed that in sparse canopies and row crops, especially under arid and semi-arid conditions, it is a significant component of the water balance that may account for $30-60 \%$ of seasonal total ET e.g. [14-16]. Nevertheless, quantification of $E$ remains a challenge.

An additional source of water loss is nocturnal transpiration $(T)$. While during the day $T$ is inevitable, at night, when little to no carbon uptake occurs in C3 and C4 plants, transpiration can be considered as water loss. Historically, nocturnal transpiration was assumed negligible [17], although some reports of nocturnal water loss were already published in the mid and late 1900s [18-21]. Recently, increasing evidence suggest that nighttime transpiration can be quite substantial, ranging from 5 to $30 \%$ of the total daily flux [22-25]. Greater rates have been reported in some extreme cases [26]. Nevertheless, studies providing evidence of nighttime water loss by crop canopies under field conditions are rare [24].

Numerous studies treat $E$ and $T$ as one combined entity referred to as evapotranspiration (ET). The number of studies aiming at quantifying and/or modeling ET is large enough to lead researchers to suggest rules and recommendations on the types of documentation that should accompany ET datasets and associated products when published [27]. Although combining $E$ and $T$ is expedient for some applications, doing so obscures biological and physical processes, which play a significant role in regulating the hydrological cycle and obscures the potential for reducing $E$ to improve water utility. This realization has led to specifying the partitioning of ET into $E$ and $T$ as one of six scientific challenges deemed central to a better understanding of the ecohydrology, as well as agrohydrology, of water-limited environments [28]. Separation of $E$ and $T$ is essential for evaluating crop growth and water use models that attempt to model WUE [29]; such models are increasingly needed to discriminate between alternative management schemes for increasing WUE. Measurement of $E$ from the soil surface of irrigated crops with micro-lysimeters [30-33] and estimation of $T$ using heat balance sap flow gages [34-36] have both been shown to be successful. Rarely, all three components, i.e., ET, $E$ and $T$ were concurrently measured. The number of studies devoted to the partitioning of ET into $E$ and $T$ is relatively small, and suitable and appropriate field data to experimentally validate and verify models partitioning ET into $E$ and $T$ are lacking [37].

The present report describes a sub-study, part of the Bushland Evapotranspiration And Remote sensing EXperiment 2008 (BEAREX08) campaign [38]. The objectives of this study were (1) to quantify $E$ throughout the rapid vegetative growth phase of irrigated cotton in a strongly advective semi-arid area; (2) to study the effects of LAI, days after irrigation, and measurement location within the row on the E/ET fraction; and (3) to study the ability of microlysimeter (ML) measures of $E$ combined with sap flow gage measures of $T$ to accurately estimate ET, compared with weighing lysimeter ET data.

\section{Materials and Methods}

\subsection{Site description}

The research was conducted at the USDA-ARS Conservation \& Production Research Laboratory, Bushland, Texas $\left(35^{\circ} 11^{\prime} \mathrm{N}-\right.$ $102^{\circ} 06^{\prime} \mathrm{E}, 1170 \mathrm{~m}$ above sea level), in the US Southern High Plains. Measurements were concentrated in one of four lysimeter fields, where irrigated cotton was planted on May 21, day of year (DOY) 142,2008 , with rows oriented north-south $(\mathrm{N}-\mathrm{S})$ and row spacing of $0.76 \mathrm{~m}$. Data were collected before and during the 2nd Intensive Observation Period (IOP, July 16 to August 3, DOY 198-216, 2008) of BEAREX08 campaign [38]). Measurements began on June 26 and covered DOY 178-216. Measurements were spanned over a period including crop leaf area indices ranging from $<0.5$ to 3 and corresponding cover fractions of $0.16-0.58$.

\subsection{Measurements}

ET was measured by a large weighing lysimeter (nominally $3 \times 3 \times 2.4$-m deep) called the NE lysimeter. Detailed descriptions of the lysimeter are given by Marek et al. [39], and its location within the larger BEAREX08 campaign is described in [38]. The lysimeter was calibrated to an accuracy of $0.04 \mathrm{~mm}$ in January 2008 [40]. The change in lysimeter water storage $(\Delta S, \mathrm{~mm})$ was calculated using 15 -min means of the lysimeter mass converted to storage of water in $\mathrm{mm}$, referenced to an arbitrary zero storage value. To synchronize $\Delta S$ with ML measurements (see below), $\Delta S$ was determined from $\sim$ sunrise $(\sim 07: 00)$ to $\sim$ sunset $(\sim 21: 00)$ and again to the next morning. ET was equal to $\Delta S$, adjusted for precipitation and irrigation events, since runoff and drainage losses

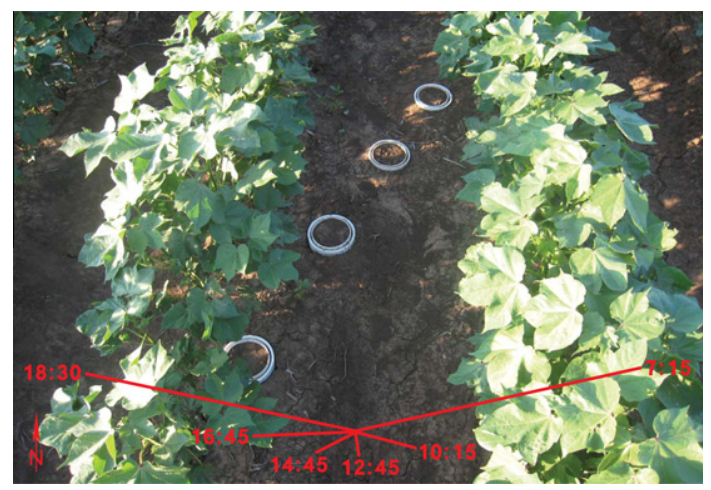

Fig. 1. The cotton field on July 24, 2008, overlaid by an illustration of the sun zenith and azimuth angles at the times of microlysimeter (ML) weighing. The direction of the lines represents the azimuth, and the length of the lines is proportional to the zenith angle, such that the higher the sun is the shorter is the line (mimicking the length of the shadow formed by an object with a given unit height). Note that only 4 MLs are apparent in the photo, the fifth ML of this set is behind the leaves at the upper part of the photo. 


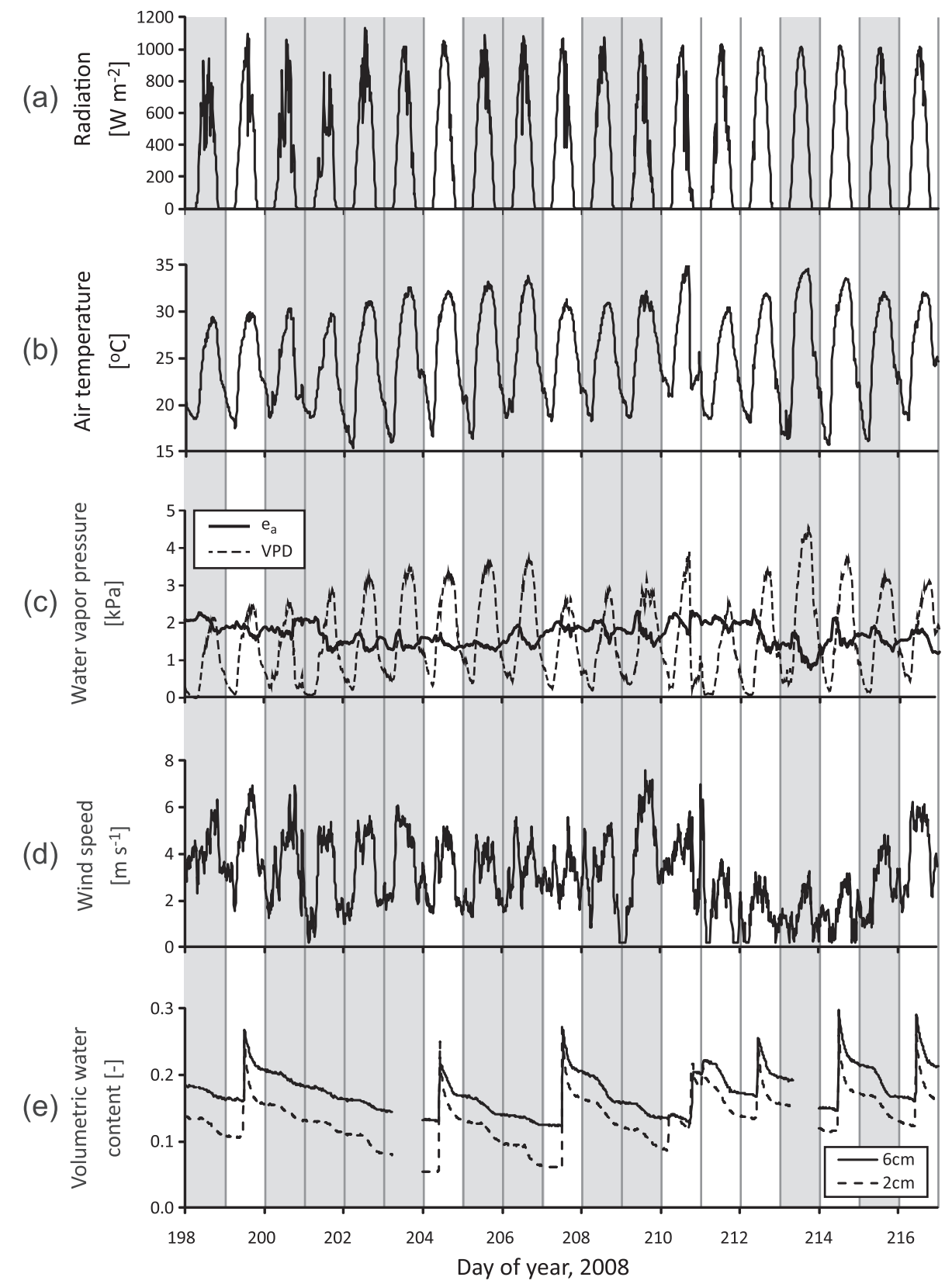

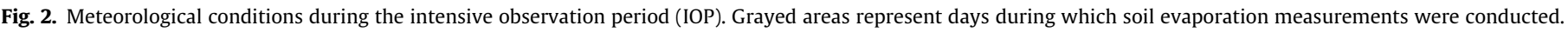
Soil water content at depths of 2 and $6 \mathrm{~cm}$ are an average of the 10 locations.

were zero (see [40]). Irrigation depths of $15-25 \mathrm{~mm}$ were applied every 2-4 days using mid elevation spray heads spaced at $1.5 \mathrm{~m}$ on a lateral move irrigation system. The peak application rate was approximately $50 \mathrm{~mm} \mathrm{~h}^{-1}$; and the irrigation application at any one point in the field was $15-25 \mathrm{~min}$ in duration.

In addition to the lysimeter measurements, ET was derived from a water balance approach using neutron probe measurements according to methods described by Evett [41] and Evett et al. [40] where discrepancies between the two ET measurement methods are described. In general, it was concluded that the lysimeter tended to slightly overestimate field ET, largely due to somewhat greater LAI and cover fraction on the lysimeter compared to the surrounding field. This bias in lysimeter ET was also confirmed by Alfieri et al. [42] based on an analysis of leaf area maps generated from aircraft observations and source area footprint estimates from eddy covariance towers sampling areas in the same field.
However, since measurements of $E$ and $T$ were conducted in the immediate vicinity of the NE lysimeter, ET values from the lysimeter were used for this local scale comparison.

Evaporation was measured using 10 MLs made of 8-mm thick rigid white polyvinyl chloride (PVC) tubes with $105-\mathrm{mm}$ inside diameter, $88-\mathrm{mm}$ depth and metal bottoms. The low thermal conductivity and white color of the plastic wall material minimizes heat conduction by the walls, and the metal bottoms avoid impedance of vertical heat transfer. These design features were proven to improve ML accuracy [43]. Undisturbed soil cores were replaced daily immediately after weighing at sunset. Two replicates of five MLs each were deployed level with the soil surface along a cross section of the interrow at distances from the row center of 0.075 , $0.225,0.375,0.525$, and $0.675 \mathrm{~m}$ from west to east (Fig. 1). To obtain daytime and nighttime $E$, the MLs were manually weighed at sunrise $(\sim 07: 00)$ and sunset $(\sim 21: 00)$ using an electronic scale 
with a precision of $0.1 \mathrm{~g}$ (equivalent to $0.01 \mathrm{~mm}$ water) enclosed in a covered box to avoid wind effects on the measurements. During two days (DOY 213 and 215), both after irrigation on the previous day, the MLs were weighed every two hours from sunrise to sunset to obtain a diurnal course of soil evaporation.

Transpiration from plants in an adjacent row in the field was measured using heat balance sap flow gages [44]. Ten representative plants were selected and instrumented with sap flow gages (models ${ }^{1}$ SGA-5, SGA-9, Dynamax, Inc., Houston, TX). The gages were placed on the stem at least $0.05 \mathrm{~m}$ above the soil surface and below any leaves and were covered with several layers of insulation and aluminum foil to shield the gage from external heating. Approximately $0.1 \mathrm{~W}$ of power was applied to the gage heat strips. The gage outputs were sampled at $0.2 \mathrm{~Hz}$, averaged for 30 -min, and logged on a datalogger (model CR-7, Campbell Scientific, Logan, UT). Transpiration was estimated from the sap flow of five to ten plants during the time period of 7:00-22:00. Data from identical periods were summed when comparing $E$ and $T$. Sap flow gages must fit the plant stem tightly for successful operation, and some gage data had to be rejected early in the experiment because of poor sensor contact with the plant stem, which produced erroneous readings. The number of gage data used in calculating $T$ increased during the experiment as plant stem diameter increased so that good sensor contact with the stem was achieved. Transpiration was computed using an area-based approach, i.e., the average of the selected gage outputs was multiplied by the number of plants per sample area.

The LAI was measured periodically by taking whole plant samples from $1 \mathrm{~m}^{2}$ areas (three replicates in each field), stripping the leaves and measuring their area with a leaf area meter (model 3100, LI-COR Environmental, Lincoln, NE). Plant height and width were measured in three replicates in the NE field and one replicate in the NE lysimeter.

Meteorological data (solar radiation, wind speed and direction, air temperature and relative humidity) were acquired from a standard meteorological station over a well-watered short grass plot adjacent to the field. Alfalfa reference evapotranspiration, $\mathrm{ET}_{\mathrm{r}}$, was calculated using the ASCE 2005 Penman-Monteith standardized reference evapotranspiration method [45]. Soil water content was determined using conventional TDR [46] with trifilar probes (10 replicates) inserted horizontally into the side of a soil pit adjacent to the MLs at 20 and $60 \mathrm{~mm}$ depths after which the pit was backfilled.

Aerodynamic resistance $\left(r_{\mathrm{a}}\right)$ was computed for the NE and the SE fields from eddy-covariance tower measurements described by Alfieri et al. [42]. The value of $r_{\mathrm{a}}$ was computed using measurements of mean wind speed $(u)$ and friction velocity $(u *)$ from the three-dimensional sonic anemometer using the expression $r_{\mathrm{a}}=u$ / $u *^{2}$. Mean daily $r_{\mathrm{a}}$ values were determined as the average of hourly aerodynamic resistance estimates from sunrise to sunset, excluding data when friction velocity was smaller than $0.2 \mathrm{~m} \mathrm{~s}^{-1}$ since very low $u *$ values are indicative of poor turbulent mixing and may result in an under-measurement of the moisture flux.

\section{Results and discussion}

\subsection{Meteorological and plant parameters}

Solar radiation at the site during the IOP reached a maximum of $\sim 1000 \mathrm{~W} \mathrm{~m}^{-2}$; the first days were partly cloudy and skies cleared towards the end of the IOP (Fig. 2a). Daily maximum and minimum

\footnotetext{
1 The use of trade, firm, or corporation names in this article is for the information and convenience of the reader. Such use does not constitute an official endorsement or approval by the United States Department of Agriculture or the Agricultural Research Service of any product or service to the exclusion of others that may be suitable.
}

temperatures were $\sim 29^{\circ} \mathrm{C}$ and $\sim 18^{\circ} \mathrm{C}$, respectively, at the beginning of the IOP, and $\sim 32^{\circ} \mathrm{C}$ and $17^{\circ} \mathrm{C}$, towards the end. The clearing skies resulted in daily fluctuations $\sim 4{ }^{\circ} \mathrm{C}$ larger towards the end of the study period (Fig. $2 \mathrm{~b}$ ). Water vapor pressure fluctuated most of the time between $\sim 1.3 \mathrm{kPa}$ and $2.2 \mathrm{kPa}$, with diel patterns often being obscured by weather fronts. Water vapor pressure deficit (VPD) showed a clear diel pattern with daily nighttime minimum ranging $0-0.6 \mathrm{kPa}$ and daily maximum ( noon) of $2.2-4.3 \mathrm{kPa}$. Water vapor pressure was lowest on DOY 213, reaching a minimum of $0.85 \mathrm{kPa}$ at 16:45 (Fig. 2c). Wind speed at 2-m height showed a distinct diel pattern, with calmer winds during the night, increasing in the morning, and decreasing around sunset (Fig. 2d). This pattern is opposite to that of diel wind speeds observed at greater heights above the surface where nighttime wind speeds are typically greater than daytime speeds due to better coupling with the jet stream at night after heat-driven buoyant turbulence has subsided $[47,48]$. During the IOP, winds were greater on DOY 209 and 210, followed by four days of particularly light winds. Irrigation and precipitation events were reflected by increases in the soil water content (Fig. 2e). The only precipitation event during the IOP (on DOY 210) was detected by the increase in soil water content. The cotton was in the vegetative growth stage during
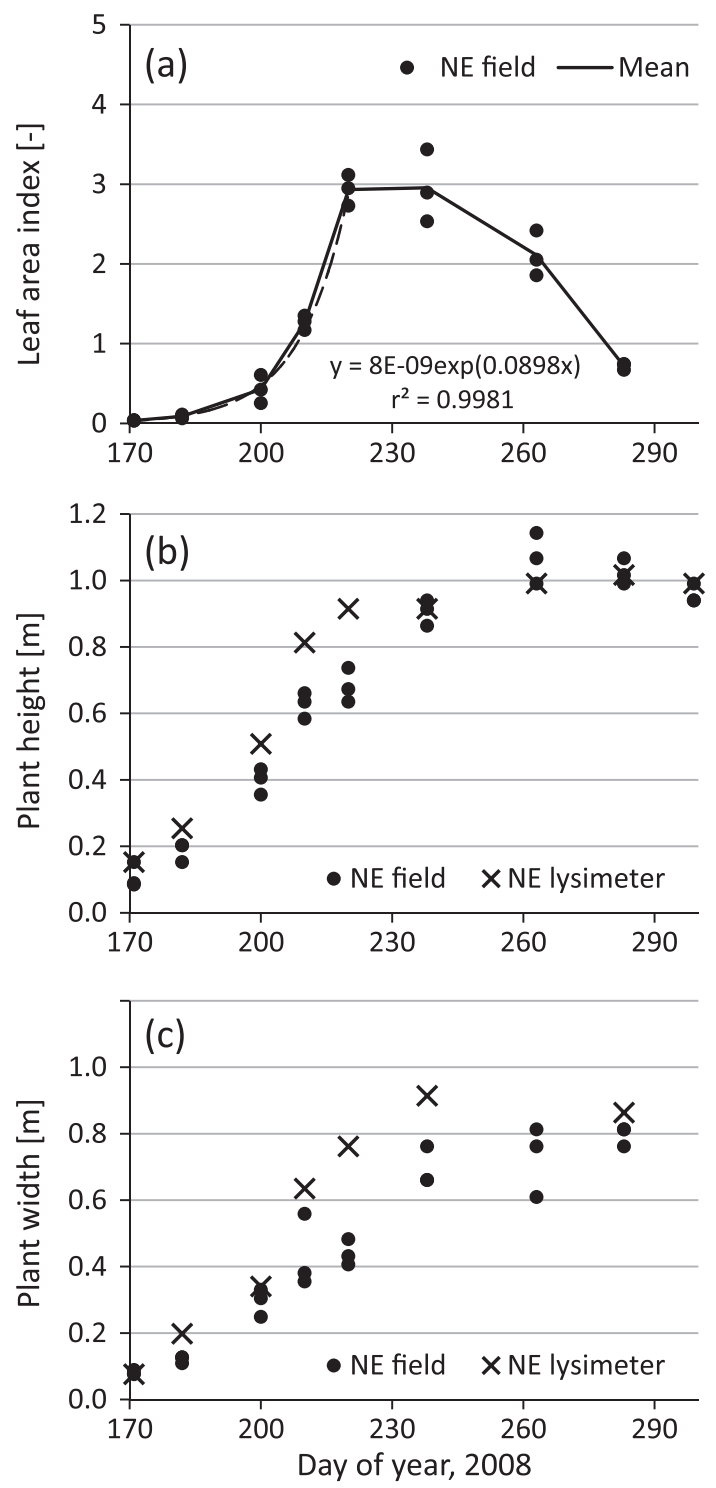

Fig. 3. Progression of measured (a) leaf area index (LAI), (b) plant height and (c) plant width in the NE lysimeter field during the 2008 cotton growing season. 
Table 1

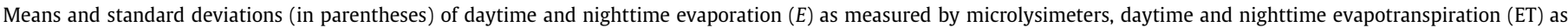

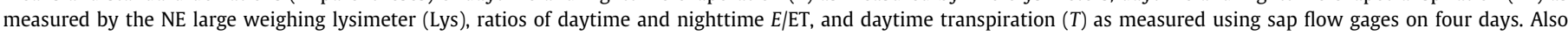

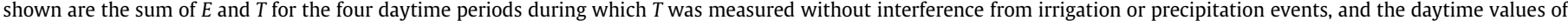

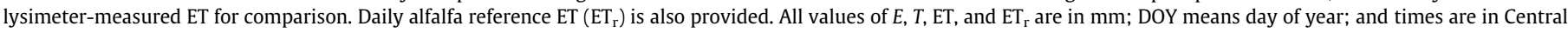
Standard Time.

\begin{tabular}{|c|c|c|c|c|c|c|c|c|c|c|c|}
\hline $\begin{array}{l}\text { Date } \\
(2008)\end{array}$ & DOY & Daytime $E$ & $\begin{array}{l}\text { Nighttime } \\
E\end{array}$ & $\begin{array}{l}\text { Daytime Lys } \\
\text { ET }\end{array}$ & $\begin{array}{l}\text { Nighttime Lys } \\
\text { ET }\end{array}$ & $\begin{array}{l}\text { Daytime E/ } \\
\text { ET }\end{array}$ & $\begin{array}{l}\text { Nighttime E/ } \\
\text { ET }\end{array}$ & $\begin{array}{l}\text { Daytime } \\
\mathrm{T}\end{array}$ & $\begin{array}{l}\text { Daytime } \\
\mathrm{E}+\mathrm{T}\end{array}$ & $\begin{array}{l}\text { E + T-Lys } \\
\text { ET }\end{array}$ & $\mathrm{ET}_{\mathrm{r}}$ \\
\hline $6 / 26$ & 178 & $\begin{array}{l}2.02 \\
(0.17)\end{array}$ & $0.13(0.06)$ & 3.76 & 0.17 & 0.54 & 0.73 & & & & 8.36 \\
\hline $6 / 27$ & 179 & $\begin{array}{l}1.57 \\
(0.16)\end{array}$ & $0.06(0.02)$ & 3.34 & 0.12 & 0.47 & 0.49 & & & & 7.53 \\
\hline $7 / 15$ & 197 & & $0.08(0.04)$ & & 0.23 & & 0.36 & & & & 5.33 \\
\hline $7 / 16$ & 198 & $\begin{array}{l}1.40 \\
(0.09)\end{array}$ & $0.12(0.03)$ & 5.61 & 0.38 & 0.25 & 0.31 & & & & 5.82 \\
\hline $7 / 18$ & 200 & $\begin{array}{l}2.69 \\
(0.80)\end{array}$ & & 6.81 & & 0.39 & & & & & 7.35 \\
\hline $7 / 19$ & 201 & $\begin{array}{l}1.90 \\
(0.39)\end{array}$ & $0.17(0.03)$ & 6.44 & 0.45 & 0.30 & 0.37 & & & & 5.94 \\
\hline $7 / 20$ & 202 & $\begin{array}{l}1.53 \\
(0.26)\end{array}$ & $0.13(0.05)$ & 7.52 & 0.46 & 0.20 & 0.29 & & & & 8.40 \\
\hline $7 / 21$ & 203 & $\begin{array}{l}1.12 \\
(0.11)\end{array}$ & $0.05(0.04)$ & 7.07 & 0.42 & 0.16 & 0.12 & 6.28 & 7.40 & 0.33 & 8.04 \\
\hline \multicolumn{12}{|c|}{ 7/22/2008 - irrigation } \\
\hline $7 / 23$ & 205 & $\begin{array}{l}1.84 \\
(0.15)\end{array}$ & $0.14(0.03)$ & 8.77 & 0.51 & 0.21 & 0.28 & 8.30 & 10.14 & 1.37 & 7.59 \\
\hline $7 / 24$ & 206 & $\begin{array}{l}1.01 \\
(0.07)\end{array}$ & $0.00(0.03)$ & 7.67 & 0.38 & 0.13 & -0.01 & 8.27 & 9.28 & 1.62 & 8.35 \\
\hline \multicolumn{12}{|c|}{$7 / 28 / 2008$ and $7 / 30 / 2008$ - irrigation } \\
\hline $7 / 31$ & 213 & $\begin{array}{l}1.99 \\
(0.20)\end{array}$ & $0.12(0.06)$ & 9.88 & 0.38 & 0.20 & 0.32 & 7.37 & 9.36 & -0.52 & 7.07 \\
\hline \multirow[t]{3}{*}{$8 / 2$} & 215 & $\begin{array}{l}2.19 \\
(0.19)\end{array}$ & $0.34(0.08)$ & 10.59 & 0.92 & 0.21 & 0.37 & & & & 8.28 \\
\hline & & & & & Mean & 0.28 & 0.33 & & & & \\
\hline & & & & & SD & 0.13 & 0.19 & & & & \\
\hline
\end{tabular}

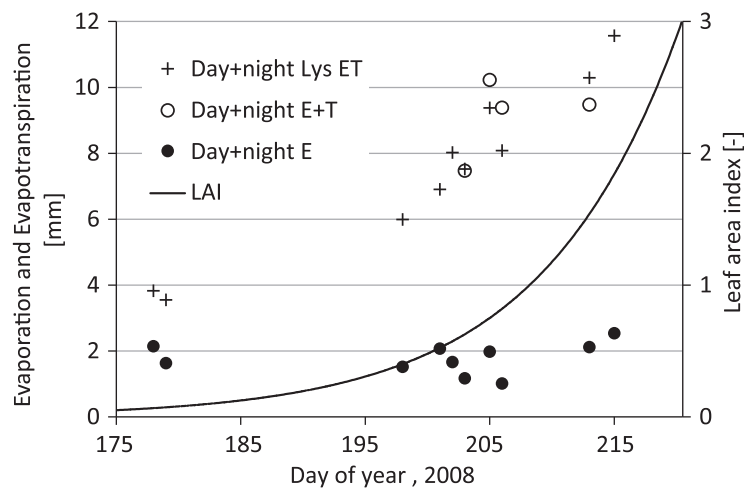

Fig. 4. Totals of daytime and following nighttime evaporation $(E)$ as measured by microlyisimeters, $E+T$ (where transpiration, $T$, was measured with sap flow gages) and weighing lysimeter (Lys) ET versus days of year (DOY). Data for DOY 178 and 179 were taken before the intensive observation period began. The LAI values were estimated from the exponential relationship shown in Fig. 3.

the IOP (DOY 198-216) as indicated by the rapid increase in LAI, from a mean of 0.43 on DOY 200 to a mean of 1.27 on DOY 210 and a mean of 2.93 on DOY 220 (Fig. 3a). An exponential function described the increase in LAI with $r^{2}=0.99$ (LAI $=8.0 \times 10^{-09}$ $\exp [0.0898 \times \mathrm{DOY}])$. Plant width increased from a mean of $0.12 \mathrm{~m}$ on DOY 182 to a mean of $0.29 \mathrm{~m}$ on DOY 200 and a mean of $0.44 \mathrm{~m}$ on DOY 220 (Fig. 3c). This translates roughly to a cover fraction change of $0.16-0.58$ over the entire measurement period considered herein and $0.29-0.58$ during the IOP.

\section{2. $E+T=E T$}

Daytime and nighttime ML measurements of $E$ were collected on 11 days. Daytime $E$ ranged from a high of $2.7 \mathrm{~mm}$ on DOY 200 to a low of $1.0 \mathrm{~mm}$ on DOY 206; and nighttime $E$ ranged from 0.05 to $0.34 \mathrm{~mm}$ (Table 1 ). The small negative value of nighttime $E$ on DOY 206-207 was due to a rainfall event that was too small to affect the rain gage but that was observed by the weighing lysimeter. Sap flow was measured during daytime on DOY 203213 (11 days), but on only four days were there concurrent sap flow estimates of $T$ and ML measurements of $E$ (Table 1, Fig. 4) without interference from irrigation or precipitation events. When daytime $E+T$ data were regressed against daytime lysimeter ET $\left(N=4\right.$, adjusted $\left.r^{2}=0.16\right)$, neither the intercept nor slope were significantly different from zero. Setting the intercept to zero resulted in a statistically significant relationship $(p=0.0004)$ with slope of $1.08 \mathrm{~mm} / \mathrm{mm}\left(\mathrm{SE}=1.04 \mathrm{~mm}\right.$, adjusted $\left.r^{2}=0.66\right)$. The standard error of $1 \mathrm{~mm}$ for daytime ET ranging from 7.1 to $9.9 \mathrm{~mm}$ indicates $>=10 \%$ overall difference, although the sum $E+T$ was greater than lysimeter ET by 1.4 and $1.6 \mathrm{~mm}$ on DOY 205-206 (Table 1, Fig. 4).

When irrigations occurred, $T$ was reduced due to the humidification of the atmosphere within the canopy (Fig. 5). A secondary effect that would have acted to reduce $T$ was that the canopy was cooled by the irrigation, which would have reduced the vapor pressure gradient by depressing the sub-stomatal vapor pressure. Decreases of in-canopy vapor pressure deficit and of corn (Zea mays L.) $T$ during, and shortly after, irrigation were reported by Cavero et al. [34], Martinez-Cob et al. [35], and Tolk et al. [36]. Decreases in $T$ compensated for evaporation of canopy-intercepted water, which helped to improve irrigation application efficiency. In the present study, while $T$ increased after the irrigation event, absolute rates tended to not greatly exceed $0.8 \mathrm{~mm} \mathrm{~h}^{-1}$, even on days when ET absolute rates approached or exceeded $1.2 \mathrm{~mm} \mathrm{~h}^{-1}$. It appeared that cotton physiology and root water uptake processes were limiting the maximum $T$ rate.

Transpiration exceeded ET on a few occasions and was essentially equal to ET on DOY 205 (Fig. 5). Given the equality ET $=E+T$ and since $E$ was not negligible, values of $T$ equal to, or larger than, 

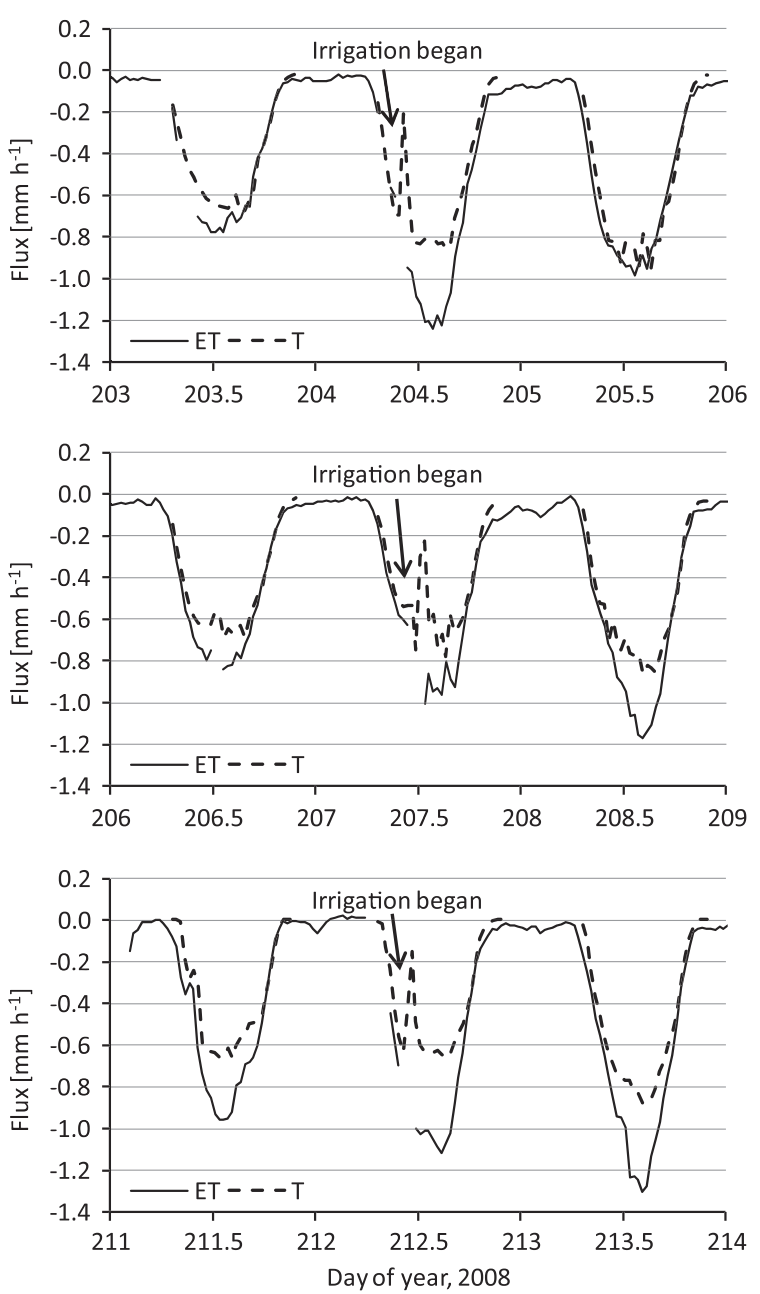

Fig. 5. Suppression of transpiration $(T)$ during irrigation events on days of the year 204, 207 and 212, 2008. Also shown are ET and $T$ on days before and after those irrigations. Discontinuities in ET data are due to irrigation or precipitation (day of year 203) events.

ET indicate that $T$ was likely over estimated. The problems with comparing sap flow data to lysimeter data were that (i) the number of plants with gages (5-10 plants) was much less than the lysimeter population of 135 plants, and (ii) the lysimeter plant population, although within $30 \mathrm{~m}$ of the sap flow gage installation and thinned to the same plant density, was somewhat different in phenology, with plant width and height sometimes larger on the lysimeter than in the field (Fig. $3 \mathrm{~b}$ and $\mathrm{c}$ ). The determination made by Evett et al. [40] and Alfieri et al. [42] that the NE lysimeter ET values were greater than field scale estimates of ET further supports the indication that $T$ was over estimated by the sap flow method, which likely derives from the areal estimation process for converting sap flow data to $T$ data. Dugas [49] found that adjusting sap flow of cotton by a stem area ratio factor produced sap flow $T$ that was about 9\% larger than lysimetrically measured $T$. He noted that determining measurement accuracy was confounded by plant-to-plant variability. Adjustment of $T$ on a leaf area basis was not possible in our case because leaf area of the plants on which sap flow gages were installed was not available.

\subsection{Ratio of daily total E to ET}

Daytime $E$ averaged $28 \%$ of lysimeter ET (Table 1 ). The daily fraction $E / E T$ throughout the study period showed two phenomena

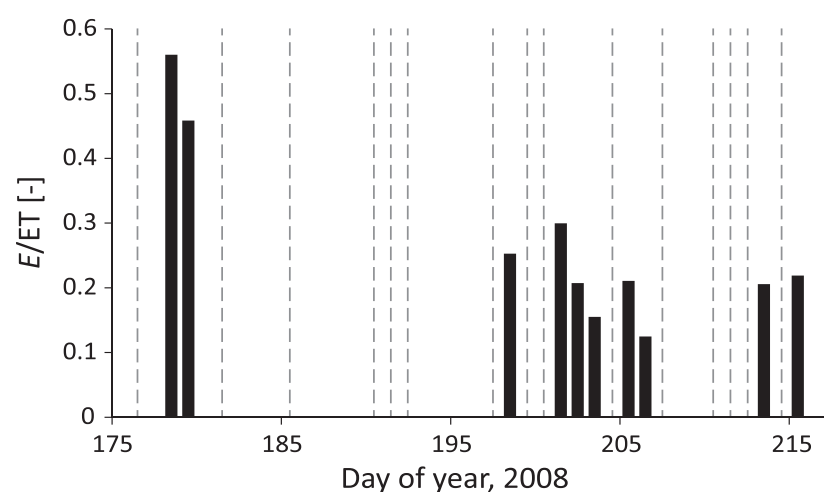

Fig. 6. Daily fractions of soil evaporation (E) from evapotranspiration (ET). Gray dashed lines represent rainfall or irrigation events.

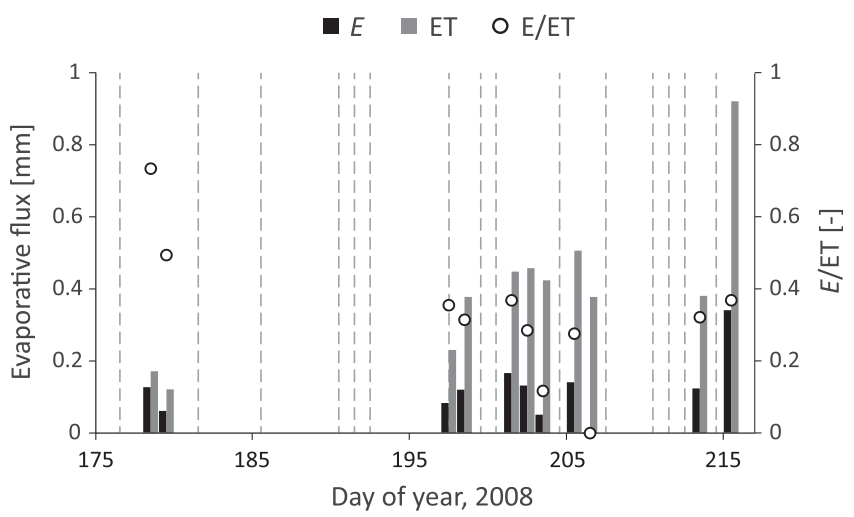

Fig. 7. Nocturnal soil evaporation (E), evapotranspiration (ET), and the fraction E/ET. Gray dashed lines represent rainfall or irrigation events.

(Fig. 6). First, a steady decline of E/ET on successive days after irrigation or precipitation events occurred for the four events shown in Table 1. Second, a reduction in the E/ET ratio as LAI increased was observed. The largest values of daytime E/ET occurred on DOY 178, before the IOP (DOY 198-215), when LAI < 0.5. The smallest values of daytime E/ET on days immediately after irrigation or precipitation occurred near the end of the IOP when LAI was closer to 3 . Early in the growing season, when LAI was $<0.2$ and canopy cover was less than $10 \%, E$ was $\sim 50 \%$ of daily ET. As LAI approached 2 , daily $E$ on the day after irrigation or precipitation was closer to $20 \%$ of daily ET. Somewhat surprisingly, the daily $E$ did not decrease greatly as LAI increased from 0.05 to nearly 3 (Fig. 4), remaining at approximately $2 \mathrm{~mm} \mathrm{~d}^{-1}$ from DOY 178-215.

\subsection{Nocturnal E, $T$ and $E T$}

Nighttime (21:00-07:00) ET ranged from $0.12 \mathrm{~mm}$ to $0.92 \mathrm{~mm}$ (Fig. 7, Table 1). In comparison, Tolk et al. [23] reported mean nighttime ET ranging from 0.52 to $0.58 \mathrm{~mm}$ for irrigated alfalfa (Medicago sativa L.), with some nighttime losses approaching $2 \mathrm{~mm}$, and mean nighttime ET of 0.31 and $0.41 \mathrm{~mm}$ for dryland and fully irrigated cotton, respectively. On average, nighttime lysimeter ET in the present experiment was $6 \%$ of daily totals. Similarly to patterns observed for the total daily fluxes, nocturnal E/ET was larger earlier in the growing season with an average of 0.61 for DOYs 178-179, and reduced as the canopy developed with an average of 0.30 for DOYs $198-215$. In comparison, total daily E/ET for DOYs 198-215 was 0.21 . This means that nocturnal transpiration was $5 \%$ of total daily transpiration. This fraction is within the lower reported range [22-26]. The reduction in the fraction of $E$ with increasing time after irrigation events was also noticeable. 

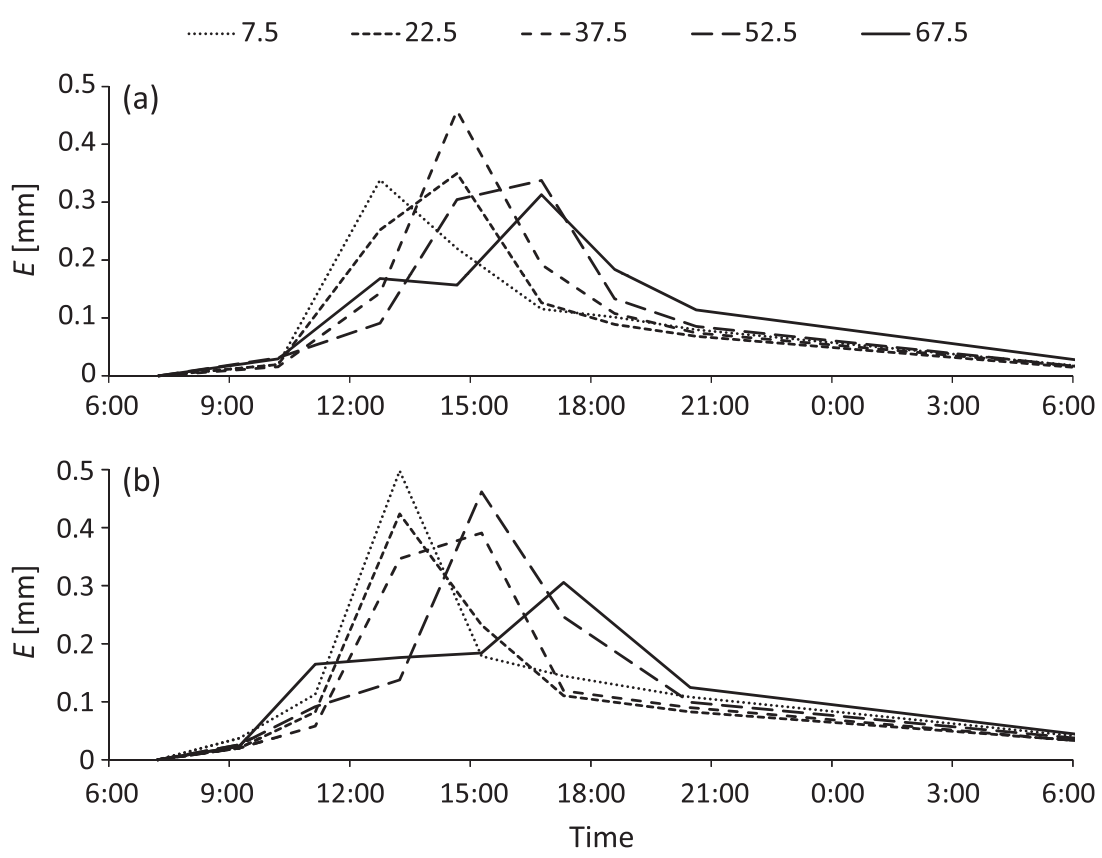

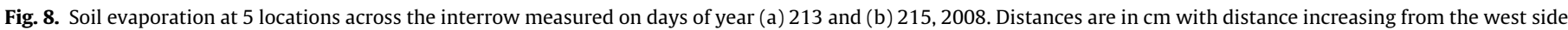
of the interrow to the east side.
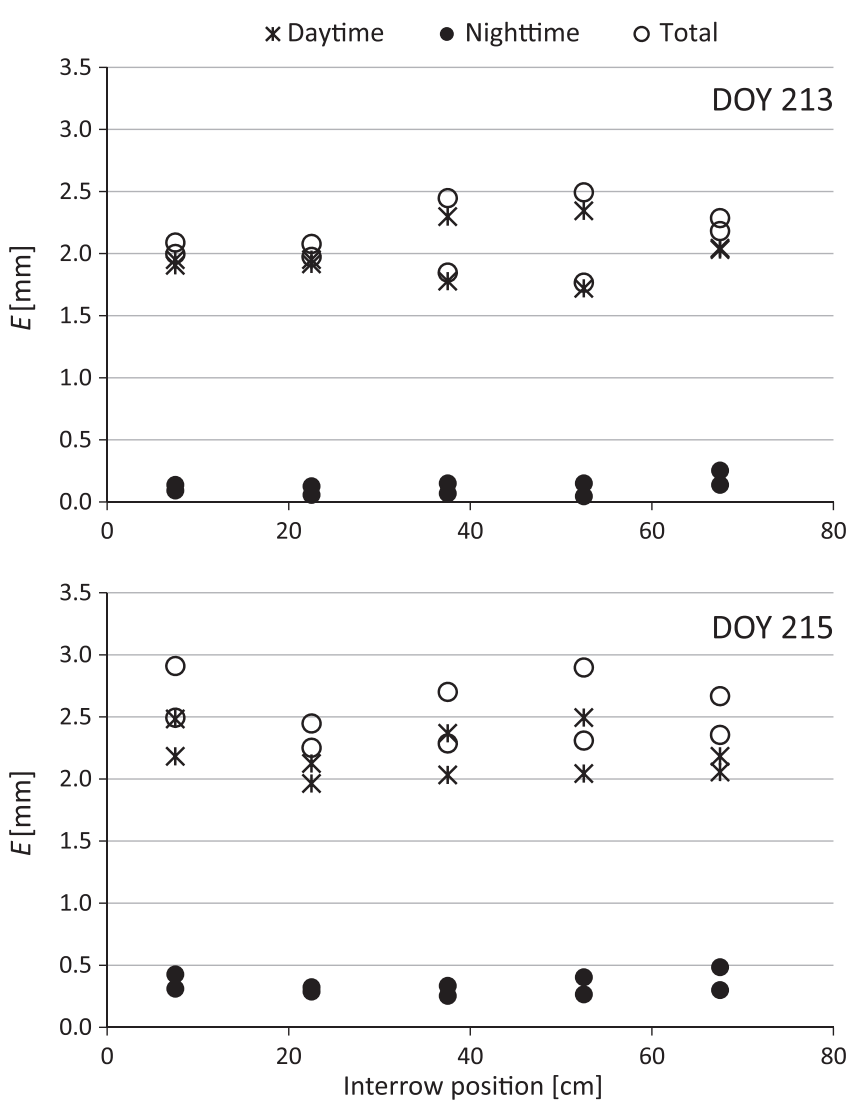

Fig. 9. Total daily evaporation $(E)$ and daytime and nighttime $E$ totals by position from the west side of the interrow for days of the year 213 and 215, 2008.

\subsection{Diel dynamics of $E$}

To better understand the dynamics of soil evaporation in a semi-arid row-crop system, the diurnal course of $E$ during two days was analyzed. Measurements were made at approximately twohour intervals during the daylight hours for the two days, both of them after irrigation on the previous day, which made soil water conditions similar. Over both periods, a distinct effect of measurement location on $E$ was apparent, with a shift in time of peak $E$ from west to east (Fig. 8). This pattern was governed by the solar radiation reaching the soil surface (see Fig. 1 for sun azimuth and zenith angles at the times of measurement). In the morning, the presence of the crop and the sun's position formed shadows on large fractions of the interrow, allowing for radiation to reach the soil only at the narrow western part of the interrow. Therefore, only the western MLs were exposed to direct solar radiation, which drove evaporation. Near noon, sun elevation was higher with a southerly direction (i.e., parallel to the row), and the only shaded areas were those immediately below the canopy, resulting in a peak $E$ at the central ML. In the afternoon and evening, only the eastern part of the interrow was exposed to direct solar radiation, resulting in a peak $E$ from the eastern MLs.

Despite the observed differences between locations in the pattern of diurnal $E$, total daily $E$ values were not noticeably influenced by position on any of the 11 days during which $E$ was measured (Fig. 9). Moreover, regressions of 24-h E on $\mathrm{ET}_{\mathrm{r}}$ and on lysimeter ET for the same 11 days both indicated no significant correlation. This implies that $E$ was not strongly influenced by evaporative demand. The lack of correlation is likely due to the strong interaction of ET with increasing plant height and LAI during the period. To further investigate the relationship between evaporative demand and $E, \mathrm{ET}_{\mathrm{r}}$ was binned in $15^{\circ}$ directional increments to find the vectors of strongest evaporative demand. During the days for which measurements of $E$ were collected, the winds and evaporative demand were from southerly directions except for DOY 213 and until 7:00 on DOY 214 when evaporative demand was from the east. The $\mathrm{ET}_{\mathrm{r}}$ was 7.07 and $8.28 \mathrm{~mm} \mathrm{~d}^{-1}$ on DOY 213 and 215, respectively (Table 1), i.e., 17\% larger on DOY 215. The $E$ values on DOY 213 and 215 were 2.1 and $2.5 \mathrm{~mm} \mathrm{~d}^{-1}$, respectively, with that on DOY 215 being larger by $20 \%$. Since soil, crop and management conditions were similar for both days (both followed an irrigation on the previous day), these differences may be attributed to differences in weather conditions (Fig. 10). Solar 

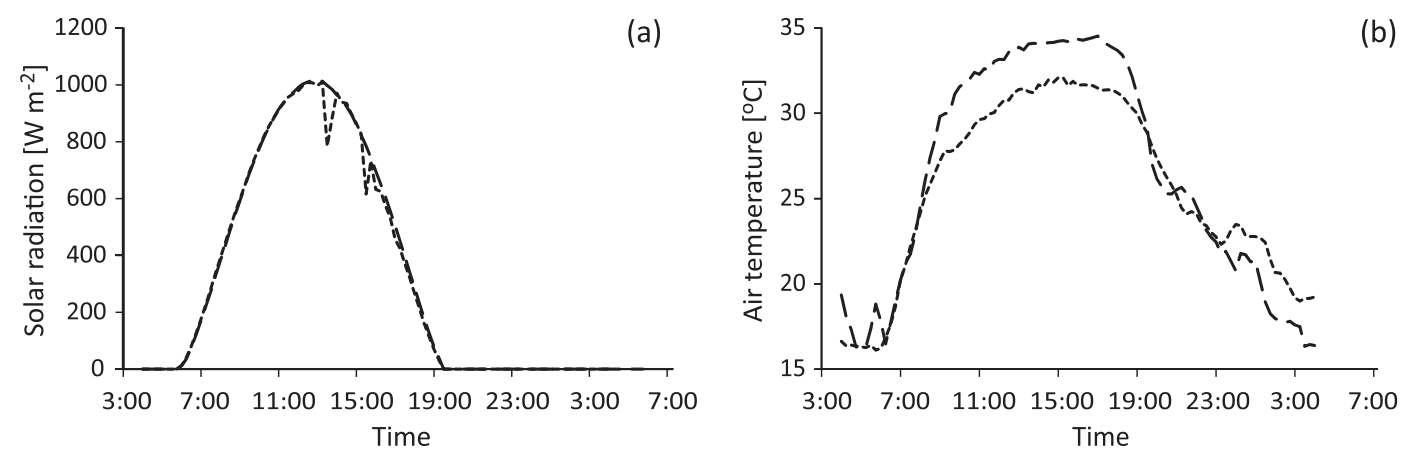

(b)
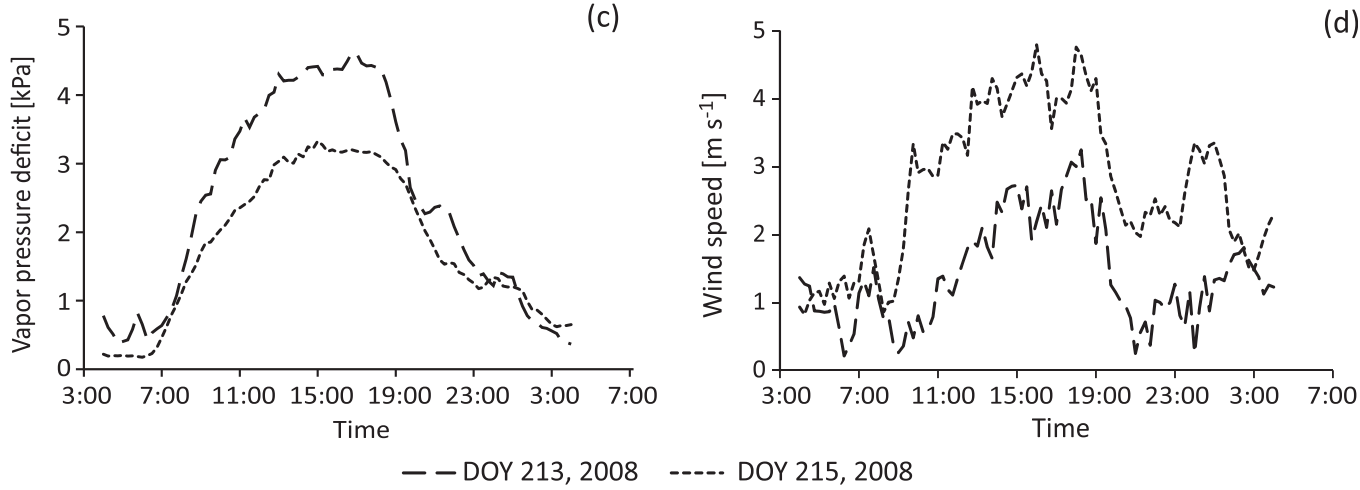

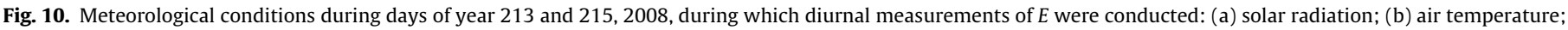
(c) vapor pressure deficit; and (d) wind speed ( $2 \mathrm{~m}$ above the ground).

DOY 213

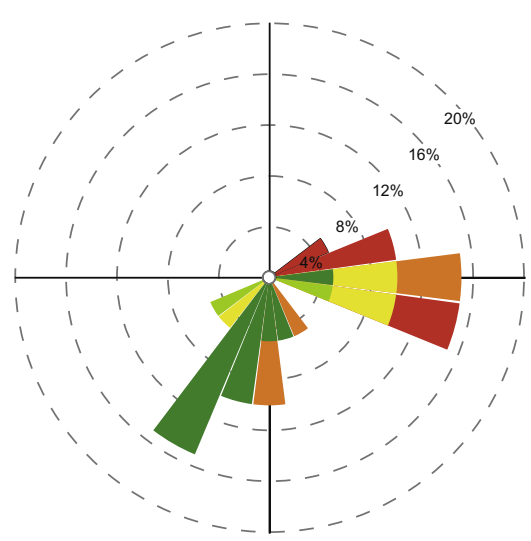

DOY 215

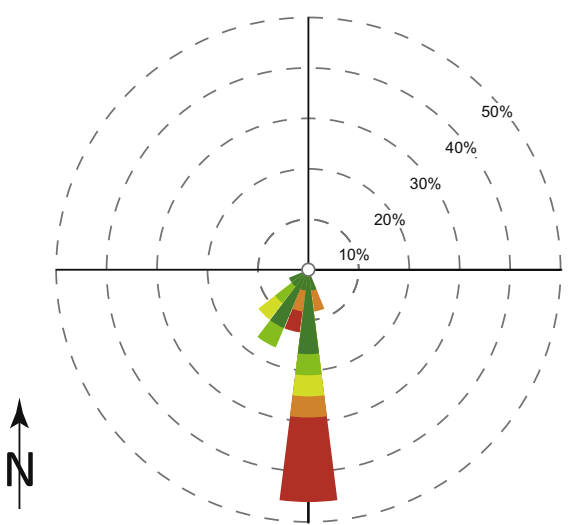

(d)

\section{Alfalfa reference ET [mm h-1]}

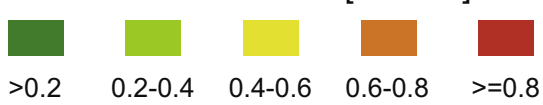

Fig. 11. Wind roses for the 24-h period and the nighttime on days of year (DOY) 213 and 215

radiation was practically the same on these two days, with a few minor reductions due to clouds on DOY 215 (Fig. 10a). Air temperature was greater during the day and somewhat smaller during the night of DOY 213 (Fig. 10b), and vapor pressure deficit was less throughout on DOY 215 (Fig. 10c). These conditions are expected to result in a greater evaporative demand on DOY 213. Still, evaporative demand was greater on DOY 215. The likely reason for this was the difference in wind speed magnitude being the overriding factor in causing greater evaporative demand on DOY 215 (Fig. 10d, Table 1).

In row crops, not only wind speed is expected to affect evaporation, but also wind direction. The differences in wind directions and speeds for the two days were distinct, causing differences in evaporative demand (Fig. 11). On DOY 213, most of the winds were less than $2 \mathrm{~m} \mathrm{~s}^{-1}$. In the few instances in which wind speed was greater (never more than $5 \mathrm{~m} \mathrm{~s}^{-1}$ ) wind direction was east, i.e., perpendicular to the rows. In such a case, the rows served as wind breaks. In contrast, on DOY 215 not only were wind speeds greater, the strong winds came from the south, i.e., parallel to the rows, so that wind speed in the interrow between the plants was likely much greater than on DOY 213.

There were no data for $E$ in the east-west (E-W) row direction in this study. Thus we could not distinguish the effect of row orientation on $E$ in terms of wind speed and direction. However, 


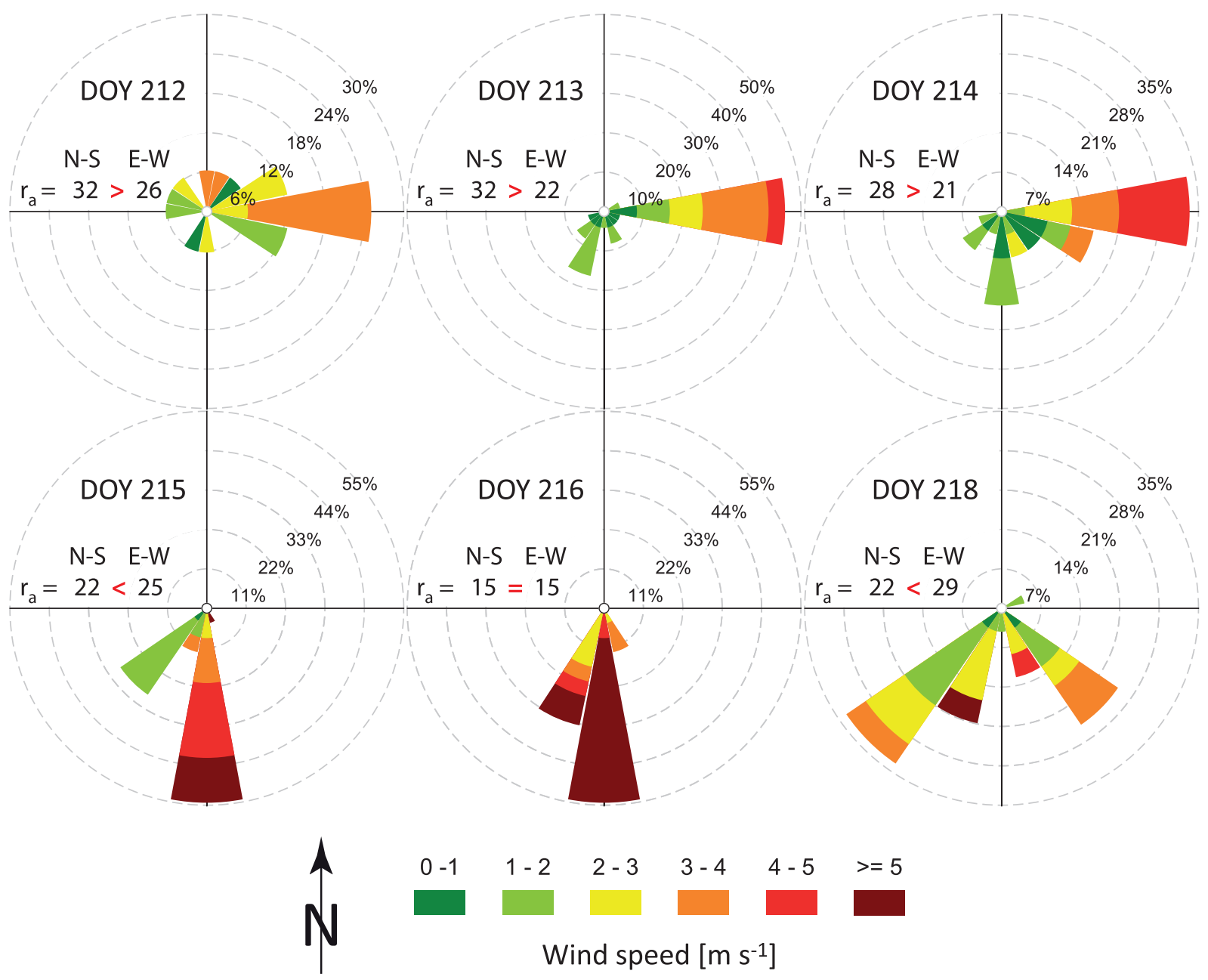

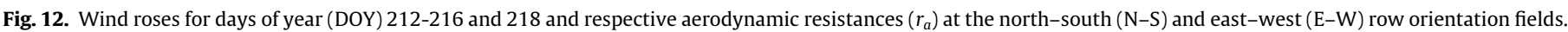

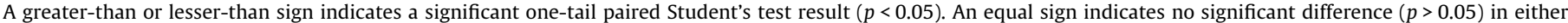
one- or two-tail tests.

comparison of daytime aerodynamic resistances $\left(r_{\mathrm{a}}\right)$ in both $\mathrm{N}-\mathrm{S}$ and E-W row orientations for six days (DOY 212-216 and 218) does suggest that wind speed magnitude and direction, in relation to the row orientation, interacted to have an effect on $E$ (Fig. 12) (Data for DOY 217 gave results very similar to 216 and is not shown). It was hypothesized that rows oriented perpendicular to the wind serve as wind breaks and thus result in larger $r_{a}$ relative to rows oriented parallel to the wind. On DOY 212-214 the dominant wind was from the east and was relatively low $(\sim 2-3 \mathrm{~m} / \mathrm{s})$. DOY 215 and 216 were characterized by stronger winds (more so on DOY 216), and predominantly from the south, while on DOY 218 the winds were again lower but were southerly, although more variable (wind direction varying from southeast to southwest). Based on the hypothesis, it was expected that $r_{a}$ would be greater in the N-S versus E-W row oriented field on DOY 212214 , and vice versa for DOY 215,216 , and 218 . One-tailed paired Student's t-tests verified the hypothesis for all days except for DOY 216, which had wind speeds exceeding $5 \mathrm{~m} \mathrm{~s}^{-1}$ over half the day. On DOY 216, no significant difference in $r_{a}$ was found between the two fields, which suggests that, for windy days, row orientation has no measurable effect on the rate of $E$. However, for low to moderate wind speed conditions (i.e., $\sim 1-4 \mathrm{~m} / \mathrm{s}$ ), rows oriented perpendicularly to the wind can serve as effective wind breaks and may result in decreased turbulent transport of $E$.

Steiner [50,51] showed that for a $0.76-\mathrm{m}$ row width planting of a sorghum crop in Bushland, row orientation affected light interception with $\mathrm{N}-\mathrm{S}$ rows intercepting more radiation and having smaller net radiation versus $\mathrm{E}-\mathrm{W}$ rows. These observations tend to indicate that, in terms of radiation, $\mathrm{N}-\mathrm{S}$ row orientation may result in smaller $E$ compared to E-W row orientation. Since wind direction is often variable from hour to hour and day to day, the magnitude and direction of the wind can either enhance or dampen the effects of radiation and evaporative demand on $E$ due to row orientation. Minimization of $E$ is one of the ways to improve WUE, thus the relative effect of row orientation on radiation interception and inter-row aerodynamics on the magnitude of $E$ should be further explored.

\section{Summary and conclusions}

The objectives of this study were to quantify the fractions of $E$ and $T$ compared to ET throughout part of the growing season of irrigated cotton in a strongly advective semi-arid area, and to study the effects of LAI, days after irrigation, wind direction and measurement location within the row on $E$ and the $E /$ ET fraction.

Conclusions are:

- Soil evaporation measured with microlysimeters and canopy transpiration measured with heat balance sap flow gages were combined with moderate success ( $\mathrm{SE}=1 \mathrm{~mm}$ or $\sim 10 \%$ of lysimeter ET) to separate evapotranspiration into its two components in this irrigated cotton field. 
- Depending on irrigation frequency, soil evaporation may account for $>50 \%$ of daytime evapotranspiration and $>70 \%$ of nighttime ET during early stages of plant growth (LAI $=0.02$ to $\sim 2.0$ ). These percentages are reduced with increase in LAI, mainly due to increase in transpiration (daily soil evaporation remained practically the same throughout).

- Nighttime lysimeter ET was $6 \%$ of daily totals. Nocturnal E/ET was larger earlier in the growing season, and reduced as the canopy developed. Nocturnal transpiration was $5 \%$ of total daily transpiration.

- Measurement location within the interrow distinctly affected the diurnal course of soil evaporation, with a shift in the time of peak $E$ rate from west to east. This pattern is governed by the solar radiation reaching the soil surface.

- Despite the diurnal variation in the spatial pattern of $E$, the total daytime or nighttime $E$ was not significantly affected by interrow position of the microlysimeters, indicating that microlysimeters may be used for daily evaporation measurement without regard to interrow position.

- Under low to moderate wind speed conditions $(\sim 1-4 \mathrm{~m} / \mathrm{s})$, rows oriented perpendicular to the wind served as effective wind breaks, which was related to greater resistance to the turbulent transport of $E$. Under higher wind speed conditions, row orientation had no measurable effect on the rate of $E$. More detailed studies under $\mathrm{N}-\mathrm{S}$ and $\mathrm{E}-\mathrm{W}$ row orientations and a range of canopy cover conditions are required to assess the relative influence of the different meteorological forcings on the magnitude of $E$.

\section{Acknowledgements}

We gratefully acknowledge support from the USDA-ARS Ogallala Aquifer Program, a consortium between USDA-Agricultural Research Service, Kansas State University, Texas AgriLife Research, Texas AgriLife Extension Service, Texas Tech University, and West Texas A\&M University. Travel support for the research was provided by USDA-ARS.

\section{References}

[1] Gurdak JJ, CD Roe. Review: Recharge rates and chemistry beneath playas of the High Plains aquifer, USA. Hydrogological J 18 (2010) 1747-72.

[2] Opie J. Ogallala: water for a dry land. Lincoln, NB: University of Nebraska Press; 2000.

[3] Dennehy KF, Litke DW, McMahon PB. The High Plains aquifer, USA: groundwater development and sustainability. in: KM Hiscock, MO Rivett, RM Davison, (Eds.). Sustainable groundwater development. Geological Society of London Special Publication2002. pp. 99-119.

[4] Almas LK, Collete WA, Warminski PL. Reducing Irrigation Water Demand with Cotton Production in West Texas. the Southern Agricultural Economics Association Annual Meetings, Mobile, Alabama, 2007.

[5] Chen SY, Zhang XY, Sun HY, Ren TS, Wang YM. Effects of winter wheat row spacing on evapotranpsiration, grain yield and water use efficiency. Agr Water Manage 2010;97:1126-32.

[6] Mellouli HJ, B van Wesemael, J Poesen, R Hartmann. Evaporation losses from bare soils as influenced by cultivation techniques in semi-arid regions. Agr Water Menage 2000;42:355-69.

[7] Zhang XY, Chen SY, Pei D, Liu MY, Sun HY. Evapotranspiration, yield and crop coefficient of irrigated maize under straw mulch. Pedosphere. 2005; 15:576-84.

[8] Lamm FR, Manges HL, Stone LR, AH Khan, DH Rogers. Water requirement of subsurface drip-irrigated corn in northewest Kansas. Trans Am Soc Agr Eng 1995;38:441-8.

[9] Stroosnijder L. Soil evaporation - test of a practical approach under semiarid condition. Netherlands J Agr Sci 1987;35:417-26.

[10] Zegada-Lizarazu W, Berliner PR. Inter-row mulch increase the water use efficiency of furrow-irrigated maize in an arid environment. J Agron Crop Sci 2010;197:237-48.

[11] Burt CM, Mutziger AJ, Allen RG, Howell TA. Evaporation research: Review and interpretation. J Irrigation Drainage Eng 2005;131:37-58.

[12] Jensen ME, Wright JL, Pratt BJ. Estimating soil moisture depletion from climate, crop, and soil data. Trans Am Soc Agr Eng 1971;14:954-9.
[13] Stanhill G. Evaporation, transpiration and evapotranspiration: A case for Ockham's Razor. In: Hadas A, Swartzendruber D, Rijtema PE, Fuchs M, Yardn B, editors. Physical aspects of soil water and salts in ecosystems. Berlin: Verlag; 1973. p. 207-20.

[14] Cooper PJM, Keatinge JDH, Hughes G. Crop evapotranspiration - a technique for calculation of its components by field measurements. Field Crops Res 1983;7:299-312.

[15] Eastham J, Gregory PJ, Williamson DR, Watson GD. The influence of early sowing of wheat and lupin crops on evapotranspiration and evaporation from the soil surface in a Mediterranean climate. Agr Water Manage 1999;42:205-18.

[16] Liu CM, Zhang XY, Zhang YQ. Determination of daily evaporation and evapotranspiration of winter wheat and maize by large-scale weighing lysimeter and micro-lysimeter. Agr Forest Meteorol 2002;111:109-20.

[17] Fogg GE. Photosynthesis. London: The English Language Book Society and English Universities Press; 1968.

[18] Holmgren P, Jarvis PG, Jarvis MS. Resistances to carbon dioxide and water vapour transfer in leaves of different species. Physiologia Plantarum 1965;18.

[19] Hygen G, Midgaard E. A reinvestigation of the influence of varying air humidity on cuticular transpiration in pinus silvestris L. Phisiologia Plantarum 1954;7:128-40.

[20] Muchow RC, MM Ludlow, MJ Fisher, RJK Myers. Stomatal behaviour of kenaf and sorghum in a semi arid tropical environment I. During the night. Aust J Plant Physiol 1980;7:609-19.

[21] Rawson HM, Clarke JM. Nocturnal transpiration in wheat. Aust J Plant Physiol 1988; 15:397-406.

[22] Novick KA, Oren R, Stoy PC, Siqueira MBS, Katul GG. Nocturnal evapotranspiration in eddy-covariance records from three co-located ecosystems in the Southeastern US: Implications for annual fluxes. Agr Forest Meteorol 2009;149:1491-504.

[23] Tolk JA, Howell TA, Evett SR. Nighttime evapotranspiration from alfalfa and cotton in a semiarid climate. Agron J 2006;98:730-6.

[24] Caird MA, Richards JH, Hsiao TC. Significant transpirational water loss occurs throughout the night in field-grown tomato. Funct Plant Biol 2007;34: 172-7.

[25] Caird MA, Richards JH, Donovan LA. Nighttime stomatal conductance and transpiration in C-3 and C-4 plants. Plant Physiol 2007;143:4-10.

[26] Snyder KA, Richards JH, Donovan LA. Night-time conductance in C-3 and C-4 species: do plants lose water at night? J Exper Botany 2003;54:861-5.

[27] Allen RG, Pereira LS, Howell TA, Jensen ME. Evapotranspiration information reporting: II Recommended documentation. Agr Water Manage 2011;98: 921-9.

[28] Newman BD, Wilcox BP, Archer SR, Breshears DD, Dahm CN, Duffy CJ, et al. Ecohydrology of water-limited environments: a scientific vision. Water Res Res 2006;42, 10.1029/2005WR004141.

[29] Evett SR, Tolk JA. Introduction: can water use efficiency be modeled well enough to impact crop management? Agron J 2009;101:423-5.

[30] Lascano RJ, van Bavel CHM. Simulation and measurement of evaporation from a bare soil. Soil Sci Soc Am J 1986;50:1127-33.

[31] Plauborg F. Evaporation from bare soil in a temperate humid climate measurement using micro-lysimeters and time domain reflectrometry. Agr Forest Meteorol 1995;76:1-17.

[32] Shawcroft RW, Gardner HR. Direct evaporation from soil under a row crop canopy. Agr Meteorol 1983;28:229-38.

[33] Walker GK. Evaporation from wet soil surfaces beneath plant canopies. Agr Forest Meteorol 1984;33:259-64.

[34] Cavero J, Medina ET, Puig M, Martínez-Cob. Sprinkler irrigation changes maize canopy microclimate and crop water status, transpiration, and temperature. Agron J 2009;101:854-64.

[35] Martínez-Cob A, Playán E, Zapata N, Cavero J, Medina ET, Puig M. Contribution of evapotranspiration reduction during sprinkler irrigation to application efficiency. J Irrigation Drainage Eng 2008;134:745-56.

[36] Tolk JA, Howell TA, Steiner JL, Krieg DR, Schneider AD. Role of transpiration suppression by evaporation of intercepted water in improving irrigation efficiency. Irrigation Sci 1995;16:89-95.

[37] Qiu GY, Momii K, Yano T, Lascano RJ. Experimental, verification of a mechanistic model to partition evapotranspiration into soil water and plant evaporation. Agr Forest Meteorol 1999;93:79-93.

[38] Evett SR, Kustas WP, Gowda PH, Howell TA. Overview of the Bushland Evapotranspiration (ET) and Agricultural Remote sensing EXperiment 2008 (BEAREX08): A field experiment evaluating techniques quantifying ET at multiple scales. Adv Water Res 2012;50:4-19.

[39] Marek TH, Schneider AD, Howell TA, Ebeling LL. Design and construction of large weighing monolithic lysimeters. Trans Am Soci Agr Eng. 1988;31 p 47784.

[40] Evett SR, Schwartz RC, Howell TA, Baumhardt RL, Copeland KS. Can weighing lysimeter ET represent surrounding field ET well enough to test flux station measurements of daily and sub-daily ET?. Adv Water Res 2012;50:79-90.

[41] Evett SR. Neutron Moisture Meters. In: SR Evett, LK Heng, P Moutonnet, ML Nguyen, (Eds.). Field Estimation of Soil Water Content: A Practical Guide to Methods, Instrumentation, and Sensor Technology IAEA-TCS-302008. p. 3954.

[42] Alfieri JG, Kustas WP, Prueger JH, Hipps LE, Evett SR, Basara JB, et al. On the discrepancy between eddy covariance and lysimetry-based turbulent flux measurements under strongly advective conditions. Adv Water Res 2012;50:62-78. 
[43] Evett SR, Warrick AW, Matthias AD. Wall material and capping effects on microlysimeter temperatures and evaporation. Soil Sci Soc Am J 1995;59:329-36.

[44] Baker JM, van Bavel CHM. Measurement of the mass flow of water in the stems of herbaceous plants. Plant Cell Environ 1987;10:777-82.

[45] Allen RG, Tasumi M, Morse AT, Trezza R. A Landsat-based energy balance and evapotranspiration model in western U.S. water rights regulation and planning. J Irrigation Drainage Syst 2005;19:251-68.

[46] Evett SR, Heng LK. Conventional Time Domain Reflectometry Systems. In: SR Evett, LK Heng, P Moutonnet, ML Nguyen, (Eds.). Field Estimation of Soil Water Content: A Practical Guide to Methods, Instrumentation, and Sensor Technology. International Atomic Energy Agency, Vienna, Austria, 2008. p. 55-72.
47] Vick BD, Starcher K, Clark RN, Traurig J. Matching wind resource in the Southern Great Plains with utility electrical loading. In: Proceedings of Global Windpower 2004, Chicago, IL, 2004.

[48] Vick BD, Clark RN. Large scale deployment of renewable energy by combining wind farms with solar thermal power plants. In: Proceedings of the American Solar Energy Association Annual Conference, Denver, Colorado, 2006.

[49] Dugas WA. Comparative measurement of stem flow and transpiration of cotton. Theoret Appl Climatol 1990;42:215-21.

[50] Steiner JL. Dryland grain sorghum water use, light interception, and growth responses to planting geometry. Agron J 1986;78:720-6.

[51] Steiner JL. Radiation balance of dryland grain sorghum as affected by planting geometry. Agron J 1987;79:259-65. 